\title{
HISTORICAL WATER RESERVOIRS \\ IN THE VICINITY OF BANSKÁ ŠTIAVNICA
}

\author{
Katarína Liptáková
}

\begin{abstract}
The unique water management system of artificial water reservoirs in the surroundings of Banska Stiavnica played a significant role in the development of dam civil engineering in Slovakia. The construction began more than 500 years ago, but the development of mining industry in the first half of the $18^{\text {th }}$ century started the important era in building of the dams. The paper investigates water reservoirs in the vicinity of Banská Śtiavnica, their history, construction reasons, reconstruction and current using. The reconstruction of water works was realized in recent years within the Project for renovation of the historical waterworks. The engineering solution of the reconstruction ensures stability and increases the safety of the dam bodies with regard to their historical character.
\end{abstract}

Keywords: water reservoirs, water management system, Banská Štiavnica, reconstruction

\section{Introduction}

Banská Štiavnica is one of the most beautiful and historically most interesting towns in Slovakia. In December 1993, the town Banská Štiavnica was awarded the highest international appraisal, when its historical center, together with the technical historical monuments in its vicinity, were included into the World's Cultural and Natural Heritage UNESCO. History of this town is from its beginning, connected with mining. The development of mining included the development of water management. This is proven by 60 original water reservoirs forming a unique water management system which laid the foundations of purposeful dam building in Slovakia. Many of them are functional even today and in spite of their respectable age they serve both to supply water and also for recreational purposes (Lichner et al., 1997, p. 8). The water management system built in the Stiavnica Hills is a model of a wise solution to a water supply problem, utilization of its energy a and perfect harmonization with the surrounding environment.

"Historic water management system together with the city of Banská Štiavnica is listed by UNESCO as part of the World Cultural and Natural Heritage under no. 400 "Banská Štiavnica and technical monuments in its surroundings". It is an important technical monument, which documents the maturity of hydraulic engineering in the past. The closest comparable water management system is 
located in the German Harz, and Freiberg, Saxony, Germany. After the abandonment of local mines, it lost its original purpose, which was to provide water for the mining industry. Currently, it is intensively used for large scale fish farming and recreation and completes the overall character of the surrounding landscape“"(Weis, Kubinský, 2014, p. 143).

The aim of the paper is to investigate water reservoirs in the vicinity of Banská Štiavnica, their history, construction reasons, reconstruction and current using. In the paper are used secondary sources of data collection as the study of literature, including relevant laws and other materials. The applied scientific methods of examination are analysis, especially historic-logical analysis, synthesis, comparison and deduction.

\section{History of the water management system}

Archeological findings from the Glanzenberg hill testify to the fact that primitive mining was developing as soon as in the Celtic times in the area of today's Banská Štiavnica. The glorious history started with the year 1238 when the town was bestowed the privileges of a royal town. From the 13th to the 18th century the Banská Štiavnica ore-field was among the richest in Europe producing both silver and gold. In the 13th century, invited German settlers arrived to Banská Štiavnica, most of them miners from the Lower German and Austrian regions. Even then, the two late Romanesque basilicas, not more than $500 \mathrm{~m}$ from each other, had already stood in the town. Its political importance was strengthened in the end of the 14th century by the founding of the Alliance of Central Slovakian Mining Towns. However, this era of prosperity was soon to be shaken by power struggles for the Hungarian throne and, this time literally, by a large earthquake (1442-1443). At the turn of the 15th and 16th centuries rich burghers and mining lords invested their money into luxurious residences. This fact was to shape the face of the town decisively. After the Hungarian army lost the battle at Mohác (1526), the town, apprehensive because of possible Turkish raids, was fortified. Toward the end of the 16th century Banská Stiavnica became the seat of the Mining Chamber and the Chief Office of the Chamber Lord, an institution which administered mines, smelting works and mints in the whole area of Central Slovakia. In 1627, gunpowder was used for breaking the stone in local mines for the first time in the world history of mining (Lichner et al., 1997). In the 18th century Banská Štiavnica had its heyday. "Silver and gold ore proceeds were highest in 1740 (681 kg of gold, $25900 \mathrm{~kg}$ of silver)" (Novák, Bárta, 2012, s. 16). The town and the surroundings are rich with technical development history, primarily connected with the prosperity of mining. And together with economic and technological development the town experienced a great boom of culture and property development. Numerous houses were rebuilt lavishly and the town became gradually a real center of social and cultural life. In the 18th century it 
boasted the third largest population in the whole Hungarian Empire. The year 1762 was another important milestone in the history of the town. It was the first technical college in the world and it brought Banská Štiavnica the status of the center of mining science and technology development in Europe. The first academic paper was read here on October 1st, 1764. Many European and world primacies in the science and technology realms are connected with the names of its professors. Later the Mining Academy merged with the Forestry Institute, forming the Mining and Forestry Academy. This school produced a great number of mining professionals who took part in the introduction of new methods and practices in mining all around the world.

\section{Construction of the water reservoirs}

In the region of Banská Štiavnica during the beginning of $16^{\text {th }}$ century until the half of the $19^{\text {th }}$ century the unique mining hydro-system was built up. The most important task for experts in those times was to find an effective source of energy that would replace the draining mechanisms propelled by human or animal power. It should also be noted that horses which were the source of working power became unavailable or too expensive due to wars. Repeated reduction combined with irregular payment of the miners' salaries caused social unrest in the town. Even though Maximilian's mining code of 1570 ordered miners to work five and a half shifts a week, each shift lasting 8 hours, the mine owners ignored this code and requested that miners work 12 to 16 hour days. This inhumane working regime resulted in a rapid increase in the mortality rate of the miners, the consequence of which negatively affected the productivity of the labor force. The critical condition of the mines in the town was discussed on several occasions by the Royal Court Chamber in Vienna which finally decided to close and abandon the mines in Banská Štiavnica and its surroundings. A mining expert and constructor, the Chief Engineer of Mining Mechanics in the Banská Štiavnica mining district Matthias Cornelius Hell (1651-1743) objected to this decision and created a plan to rescue mining in Banská Štiavnica. The plan which was met with skepticism by the Royal Court Chamber, finally landed on the table of the Emperor Charles VI. The plan attracted the Emperor's attention and he ordered the Royal Court Chamber to modify its decision and implement the plan. Hell's plan was based on the original concept of constructing a reservoir system. The collected water was supposed to supply the necessary energy to drain water from flooded mines, thus restoring mining activity. This plan was unique mainly because it was to be implemented in an environment that lacked any water flow or other surface water sources. Its source was supposed to be natural precipitation, relying especially on autumn rainfall and melting snow. Other prominent designers and builders were Joseph Karl Hell (1713-1783) son and successor of Matthias Cornelius Hell and, in particular, a brilliant mathematician, cartographer, geodesists and imperial and 
royal geometrician Samuel Mikovini (1686-1750). Mikovini reconstructed and increased the height of the walls of Hell's reservoirs, as well as designed and built new ones. He linked reservoirs into a system of water tunnels and so he enabled directing water to those places where it was necessary. He designed several kilometers long collecting and regulating ditches which were paved with stones. They led across the slopes of hills. In this way rain water was transferred to reservoirs. Thus, he completed entire water management system and solved the energy problem of Štiavnica mining up to the $20^{\text {th }}$ century.

\section{Using the water reservoirs in water management system}

More than sixty ponds together with seven pumps equipped with a pendulum-action system were built in Banská Štiavnica and its surroundings. This remarkable technical system was able to pump all the water out of the flooded mines in a short time, allowing mining to be restored. For several decades following its construction, this system allowed the mines to penetrate deeper and deeper underground. The energy accumulated in the Banská Štiavnica ponds water reservoirs - became for a long time the foundation of the town's economic prosperity. It provided energy for mining, processing, and metallurgical facilities and to a lesser extent also powered mills and plants. The most crucial part of the water management system was built in the surroundings of the municipality which is presently called Štiavnické Bane. The ponds in this part of the system contained more than a half of the volume of all collected water and with its network of acceleration and collection ditches and water tunnels, its overall energy production significantly supported the operation and function of mining in Banská Štiavnica during those days. The largest reservoir in the whole system was the Počúvadlo, which covers an area of 12.13 hectares.

In the mid-19th century a unique mining hydro-system was finished in the surroundings of Banská Štiavnica, consisting of 60 reservoirs. According to their river basins they are divided into the following groups:

- Banská Štiavnica water reservoirs (see figure 1),

- Piarg water reservoirs,

- Kolpachy water reservoirs,

- Hodruša water reservoirs (figure 2),

- Vyhne water reservoirs,

- Banská Belá water reservoirs (Lichner et al., 1997, p. 31; Novák, Bárta, 2012, p. 38). In this period there were here built total 60 reservoirs, 22 are in order today (Lukáč, Bednárová, 2006). 
Figure 1: Banská Štiavnica water reservoirs

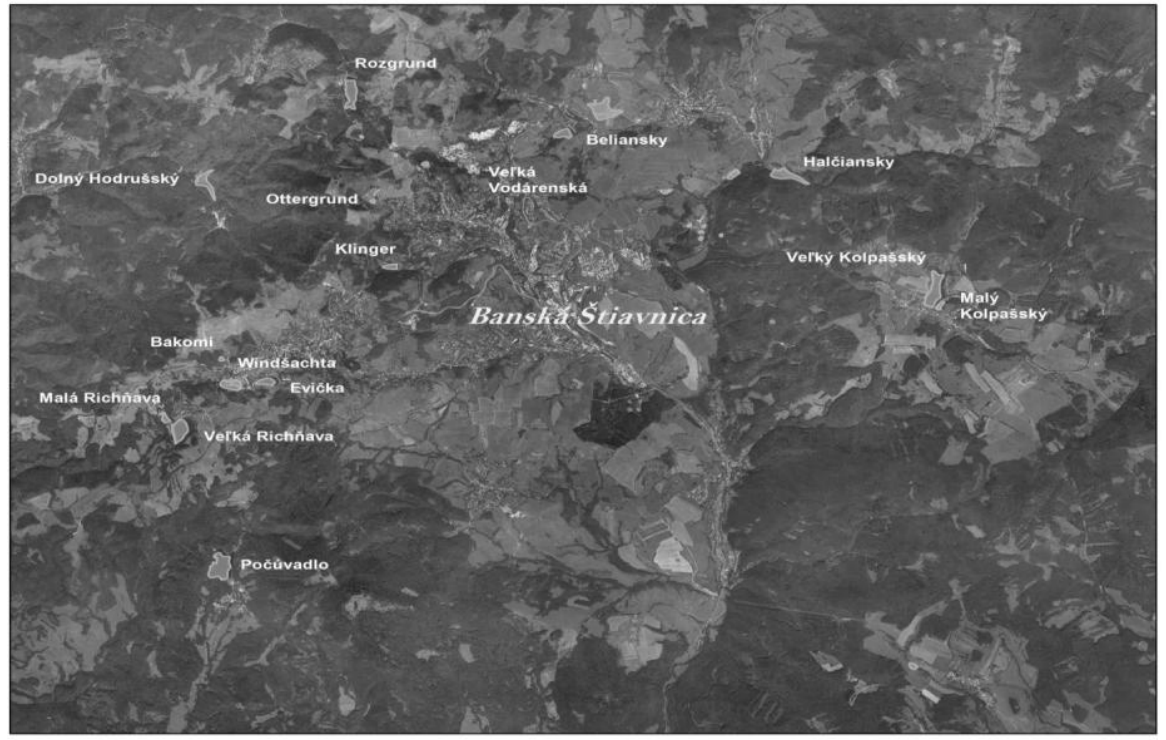

Author: Geodis Slovakia (photomap), 2009 (In Novák, Bárta, 2012, p. 6-7).

Figure 2: Original layout of the Hodruša water reservoirs

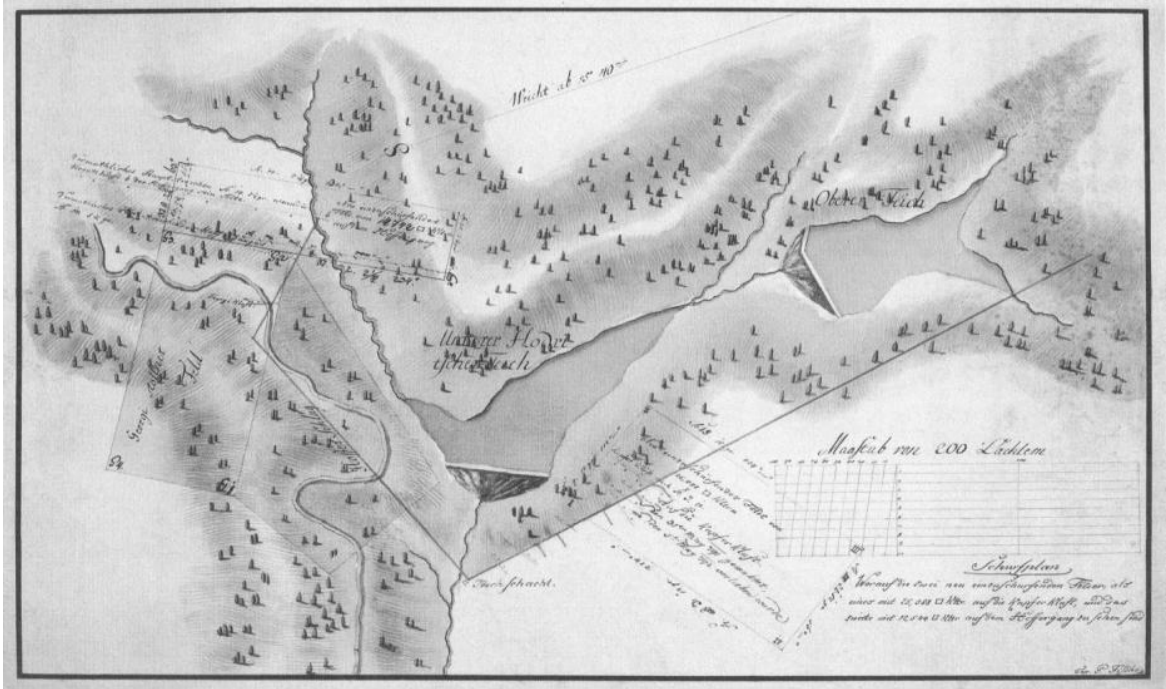

Author: a copy by P. Fischer (In Novák, Bárta, 2012, p. 108). 
"In the past, the majority of the water reservoirs in Banská Štiavnica's ore district have served to power mining, treatment and smelting devices and, in a lesser capacity, to drive forges and mills. Several of them have also served for fish breeding ponds or as sources of drinking water" (Lichner et al., 1997, p. 31). The significance of water reservoirs has changed during their existence. They were used for mining industry until the half of the $19^{\text {th }}$ century. The reservoirs became a new source of power for pumping ground water and for treatment of lower grade ores. Protection against flood is one of the important task, which the reservoirs fulfill at present. During spring months is water from melted snow and rainfall collected in water reservoirs, therefore they decrease a risk of flooding on the areas lying below dams.

\section{Using the water reservoirs for recreation}

Water reservoirs built in order to provide energy for mines are the treasures of the region waiting to be discovered. This is particularly true of their origin, historic and technical value as well as their leisure activities potential and popularity among both locals and tourists. The first news about utilization of the mining reservoirs for recreation goes back as far as the 18th century. Bathing in the reservoirs was especially popular among students of Banská Štiavnica's Mining and Forestry Academy. This was a particularly dangerous case because water from these reservoirs was led to the town and used for drinking and cooking (Lichner et al., 1997, p. 104). In the course of the first half of the 20th century Lake Počúvadlo became more and more popular. It is the largest reservoir, being a common starting point to the legendary peak of Sitno (Sitno is the highest mountain in the area with the altitude of 1009 meters above the sea level), as well as a suitable place for swimming for both adults and children, or sailing by boat and rented pedal boat. There are numerous inexpensive places where to eat, accommodation facilities of various standard. Water reservoirs Vindšachtská and Richňavská in Štiavnické Bane and Kolpašská in Banský Studenec - the place with perhaps the most sunshine during the day - are popular locations for bathing as well. Banská Štiavnica locals enjoy swimming in Vodárenská and Klinger, which are both accessible by foot -15 minutes from the town center or Belá tajch. All of them are favorite places where to go for romantic walks. Visitors can enjoy peaceful and beautiful countryside, especially in spring and autumn. Another beautiful places are Evička and Bakomi with often not a living soul around. Suitable locations for swimming include other reservoirs in the valleys visited mostly by the locals. Ottergrund, which lies close above the historical center of Banská Štiavnica, offers a beautiful view. It can be reached by the Educational Trail with lovely viewpoints of the town. In winter the lakes are a venue for skating - Vodárenská enjoys popularity among meditative ice-skaters, while Červená Studňa is the right place for ice hockey players. These artificial lakes are now very popular also among 
holiday-makers. Surrounded by the hilly landscape and picturesque scenery of the Štiavnické vrchy Mts. they provide a wonderful resort. The Štiavnické vrchy mountains offer a network of walking routes leading through areas full of historical sights (mining tunnels and surface mining areas) but, first of all, with spectacular flora and fauna. Realization of access to water for swimmers and holiday-makers on water reservoir Vel'ká Kolpašská is shawn on figure 3.

Figure 3: Realization of access to water for swimmers and holiday-makers on water reservoir Vel'ká Kolpašská (2015)

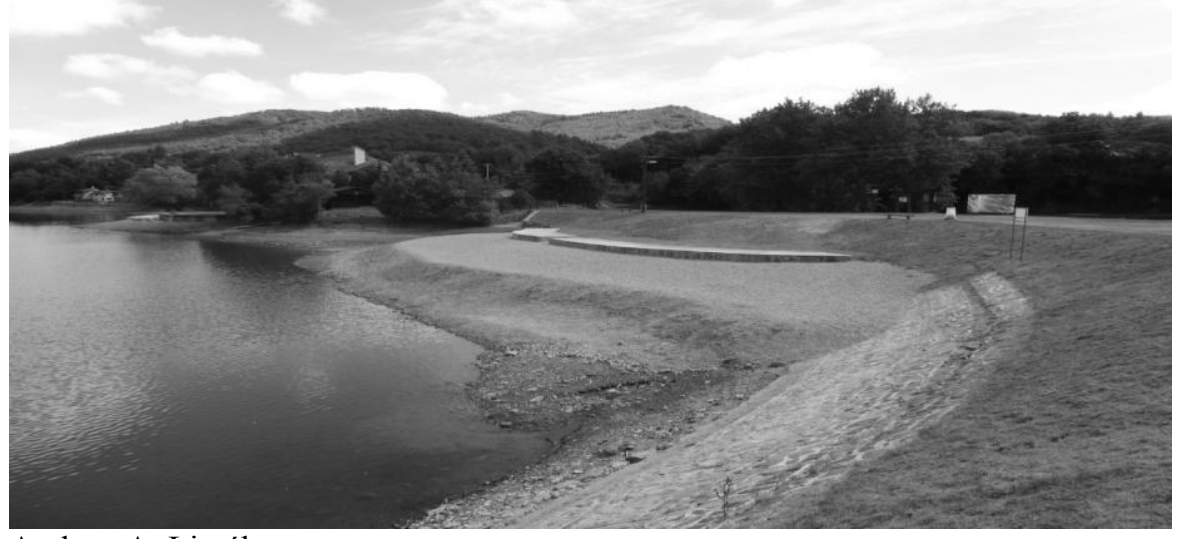

Author: A. Lipták

\section{Using the water reservoirs for fishing}

The area also provides good conditions for fishing (figure 4). Several water reservoirs are the fishing grounds mostly with carps and trouts. They are also populated by other fish, such as crucian carps, tenchs, perch, pike, zander, whitefish, grass carp, brown trout, eel and bream. Fish competitions take place at the reservoir Vindšachtská. Otherwise the fishermen can fish in a "Catch and let go" mode. "It was a duty of each chamber domain, among other tasks, to ensure a sufficient quantity of fish for mining districts and for further sale at a profit. If the population of fish in rivers and brooks was insufficient, artificial breeding in specified fishponds was introduced. The Revište Chamber Domain had such ponds in Podzámčok and Voznica, both of which fell under Banská Štiavnica's Mining Chamber" (Lichner et al., 1997, p. 106). 
Figure 4: Fishery before reconstruction of water reservoir Small Richňavská (2014)

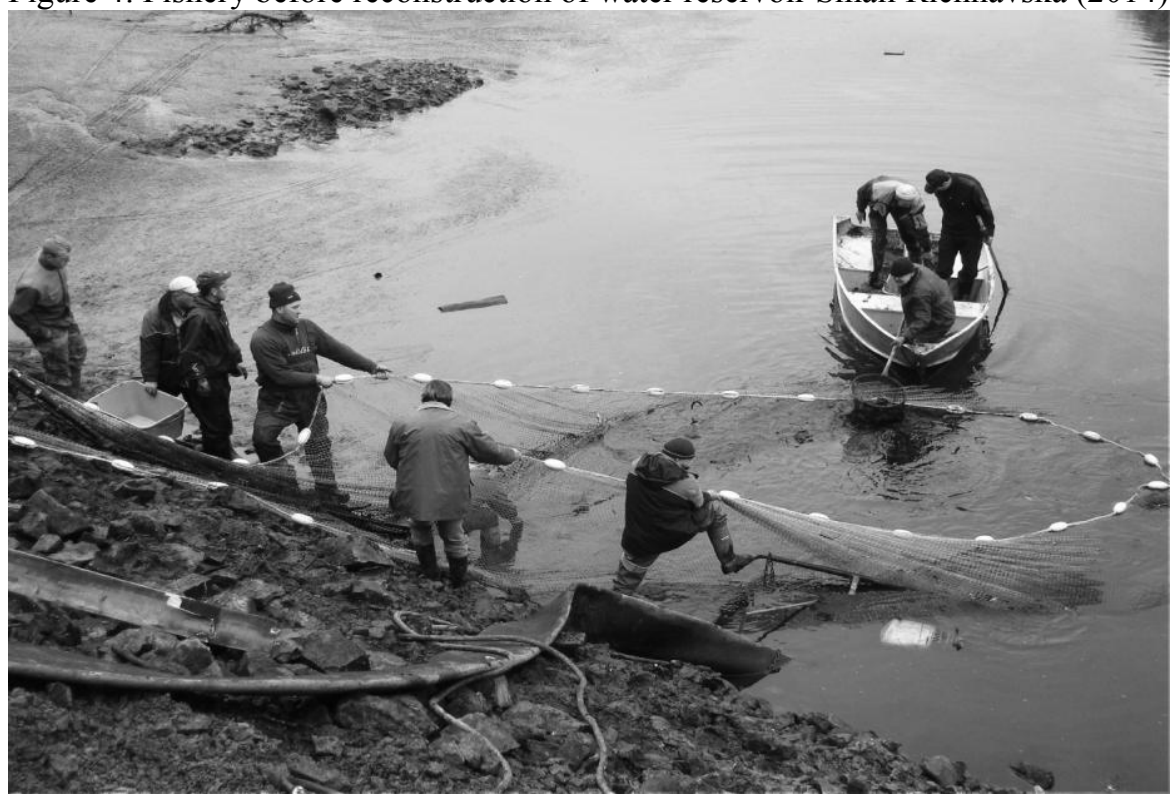

Author: A. Lipták

\section{Reconstruction of the water reservoirs}

"Slovak Water-Management Enterprise Banská Štiavnica has managed seven water reservoirs since 1983, reservoir Rozgrund already since 1981. The wind-up of company Ore Mines Banská Bystrica and agreement between the Ministry of Agriculture and the Ministry of Economy in 1995 resulted in the delimitation of management of the other fourteen water reservoirs" (Lipták, 2014). The reconstruction of water works was realized especially in the last 20 years within the Project for renovation of the historical waterworks. The engineering solution of the reconstruction ensures stability and increase of the safety of dam bodies with regard to their historical character. The most significant reconstructions of water reservoirs in recent years were:

- Moderštôlňa (1996-1997) with total cost 183269 EUR,

- Belianska (1999-2003) with total cost 582653 EUR,

- Vindšachtská (2001-2003) with total cost 206148 EUR,

- Rozgrund (2004-2006) with total cost 750316 EUR,

- Bakomi (2005-2006) with total cost 381564 EUR (figure 5),

- Small a Great Kolpašská (2007-2008) with total cost 814347 EUR,

- Small Richňavská (2014-2015) with total cost 286901 EUR. 
Figure 5: Reconstruction of water reservoir Bakomi (2006)

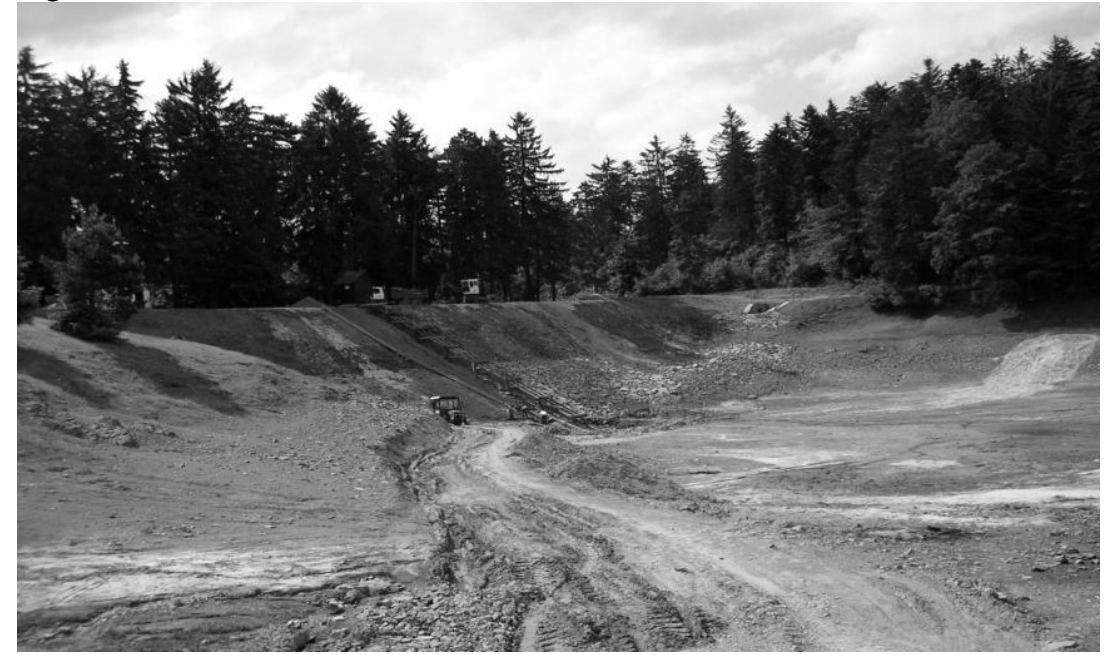

Author: A. Lipták

Grants from Cohesive Fund of the European Union within the frame of Operative program Environment operative task Protection against floods provided funds for the following:

- Evička (2012-2014) with total cost 323661 EUR (figure 6),

- Dolnohodrušská (2013-2015) with total cost 851532 EUR,

- Great Richňavská (2014-2015) with total cost 541250 EUR (figure 7).

Figure 6: Reconstruction of water reservoir Evička (2014)

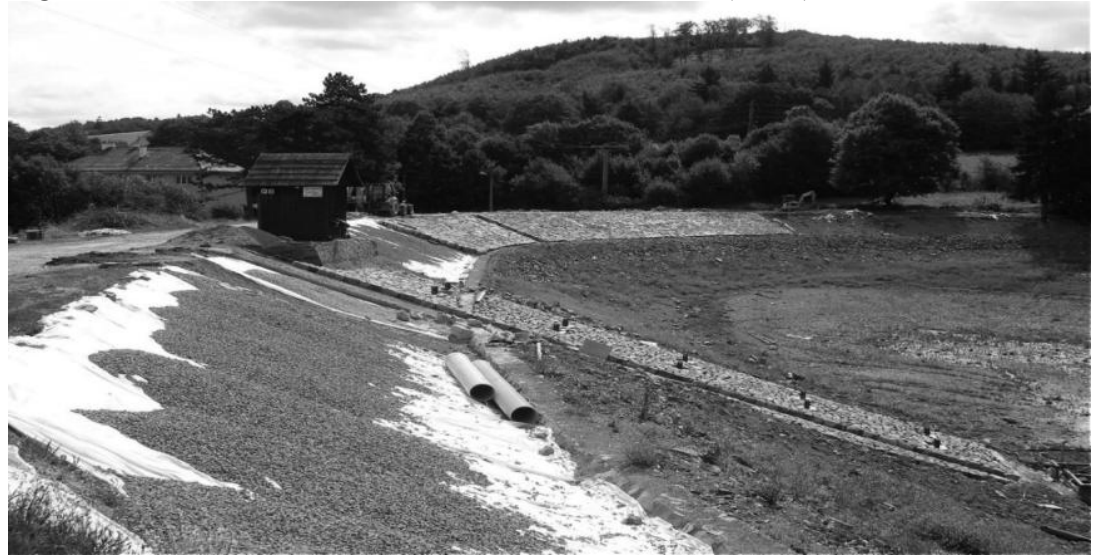

Author: A. Lipták 
Figure 7: A view on dam of water reservoir Great Richňavská after reconstruction (2015)

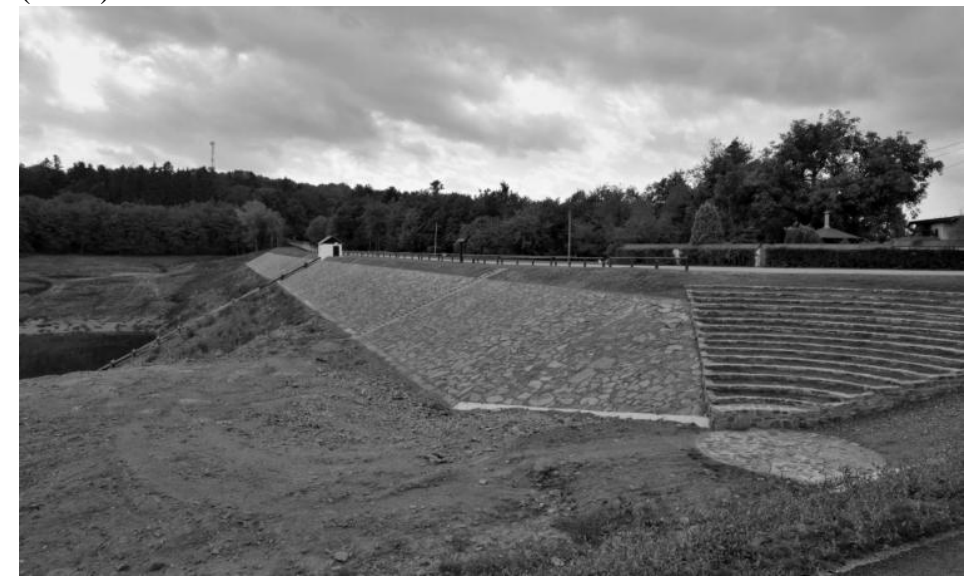

Author: A. Lipták

\section{Reconstruction of the water reservoir Rozgrund}

One of the most significant reconstruction was for example reconstruction of water reservoir Rozgrund. The reservoir is situated in the Vyhnianska valley, in an elevation of $706.20 \mathrm{~m}$. It is also one of the mining reservoirs, which is used for supply system of fresh drinking water. "The dam of the Rozgrund reservoir, built in 1744, was one of the highest earthen dams in Europe in the last century and was among the highest ones in Czechoslovakia until the middle of our century" (Lichner et al., 1997, p. 10). The dam was recognized as the most sophisticated, most efficient and most daring earth-fill dam of the time worldwide. (Novák, Bárta, 2012, p. 119). Before the reconstruction, the regulation of the reservoir volume was made by a siphon. The old wooden pipe was clogged and the closing mechanisms were out of function. The operation of the reservoir did not meet the safety requirements of the dam and its equipment and also the hygienic requirements for quality of water in the reservoir. The reconstruction works included an overall reconstruction of the embankment with replacement of bottom outlets, building a water tunnel, spillway, repair of the regulation devices and installation of a water gauge (Novák, Bárta, 2012, p. 121).

\section{Conclusion}

Banská Štiavnica's water reservoirs as unique technical relics (from overall number 21 water reservoirs, 16 reservoirs are on the state list of technical relics and 6 reservoirs are in the register of International Commission on Large Dams) 
represent high level of water management building in the $18^{\text {th }}$ and $19^{\text {th }}$ century (Lipták, 2014). "Besides retaining their immense technical and historical value, the reservoirs nowadays also act as prominent landmarks of the local countryside and key visitor attractions of the area” (Novák, Bárta, 2012, prologue). They still have a significance in the present time, their importance increase except water management importantance (protection against flood, water supply system) also by using them for recreation and fishery, which has a positive impact on rural development of Banská Štiavnica and eventually on a social - and economic development of the whole area. The water works were one of the first water management system in Europe and are evidence of the rich history of the local populations and their technical skillfulness. Global significance of the tajchs is very important. Therefore it is absolutely necessary to retain their historical character for future generations.

\section{Acknowledgement}

I want to thank to my husband Andrej, who works in Slovenský vodohospodársky podnik (Slovak Water Management Enterprise, State Enterprise Banská Štiavnica), for his help with paper's preparation. Appreciation for professional tutorial about historical water reservoirs. All enclosures are photos from his archive (e-mail andrej.liptak@svp.sk).

\section{References}

BEDNÁROVÁ, E. 2015. Vodné nádrže na Slovensku v premenách času. Available on: http://www.fyzickageografia.sk/geovedy/texty/bednarova15.pdf

LICHNER, M. - KAŠIAROVÁ, H. - NOVÁK, J. 1997. Banskoštiavnické tajchy. Liptovský Mikuláš: TELEM, TLM spol. s r. o. 109 p. ISBN: 80-967757-0-7.

LIPTÁK, A. 2014. Rekonštrukcia historických vodných stavieb vokoli Banskej Štiavnice. Available on: http://www.evizig.hu/Nemzetkozi/2_3_Liptak_A.pdf

LUKÁČ, M. - BEDNÁROVÁ, E. 2006. Navrhovanie a prevádzka vodných stavieb. Bratislava: Jaga group. 2006. 183 p. ISBN 808-07-6031-4.

NOVÁK, J. - BÁRTA, V. 2012. Tajchy v okolí Banskej Štiavnice. Slovenská L'upča: AB ART press, 142 p. ISBN 978-80-89270-72-9.

WEIS, K. - KUBINSKÝ, D. 2014. Analýza zmien objemu Halčianskej vodnej nádrže vplyvom erózie ako podklad pre manažment v povodí. In Geografie. vol. 119 , no. 2 , pp. 126-144.

\section{Doc. Ing. Katarína Liptáková, PhD.}

Katedra verejnej ekonomiky a regionálneho rozvoja, Ekonomická fakulta UMB Tajovského 10, 97401 Banská Bystrica

E-mail: katarina.liptakova@umb.sk 